\title{
Improvement of investment activity in ensuring high rates of economic growth
}

\author{
Ismatov Raxmatilla Oltinovich ${ }^{1}$ \\ ${ }^{I}$ Associate Professor of Namangan Engineering Construction Institute, Namangan, Republic of
}

Uzbekistan

Email: ismatov r@umail.uz

\begin{abstract}
In this article, organizational and economic mechanisms and peculiarities of improving investment activity in ensuring high rates of economic growth and expanding the scope of investment in the relevant sectors and sectors of the economy include modernization, technical and technological renovation of production, production, agriculture, transport and communications and others. the process of pursuing an active investment policy aimed at the implementation of social infrastructure projects has been thoroughly analyzed. Scientific and methodological aspects of stimulating the development of innovative activities based on increasing investment activity in the sectors of the economy are described.
\end{abstract}

Keywords: investment, innovation, modernization, diversification, entrepreneurship, business.

\section{INTRODUCTION}

Modernization of the economy, deepening of reforms, creation of new production capacities and fixed assets, renewal and maintenance of existing techniques and technologies in various sectors of the economy of the country depend on the correct and effective implementation of investment processes. That is why special attention is paid to the active investment policy in the republic, aimed at modernization, technical and technological renovation of production, implementation of projects in production, agriculture, transport and communication and social infrastructure. For this purpose, special attention is paid to the development and efficient use of centralized, decentralized funds, foreign investments and loans.

Based on the Strategy of Action for the five priority directions of development of the Republic of Uzbekistan in 2017-2021, at the expense of enterprises' funds, UZEX, commercial banks loans, foreign investments and loans in order to enhance its competitiveness through deepening structural reforms, modernization and diversification of the leading sectors of the national economy. - In 2021, he reviewed 649 investment projects worth $\$ 40$ billion network programs, which are carried out.

The volume of investments jointly with the World Bank, European Bank for Reconstruction and Development, Islamic and Asian Development Bank and other international financial institutions amounted to $\$ 8.5$ billion.

\section{LITERATURE REVIEW}

Scientists of the Republic of Uzbekistan BA Begalov, BA Goyibnazarov, OA Kutliev, SS Gulyamov, AJ Siddikov, KH Jumaev, H. Khujakulov, Z. Khamraev, G.B. Ernazarov, FUmarov presented the following scientific proposals based on the State Program on implementation of the Strategy of Action "The Year of Active Entrepreneurship, Innovative Ideas and Technology" in five priority areas of development of the Republic of Uzbekistan in 2017-2021: ) to modernize the industry done based on the main areas and diversification of investments in small businesses and private entrepreneurship rviojlantirishga, the process of development of foreign trade and the national economy, the prospects for the development of innovative concepts and indicators in this area through the analysis of the current socio-economic status [6]. 
B.Goibnazarov. With a view to further reforming national statistics in line with international standards, using international experience, a wide range of training courses are highly competitive in the implementation of national statistics, based on the principles and principles of national accounting standards 2008. There have been scientific suggestions that investment is a key criterion in human resources training [7].

A. Siddikov. High R\&D of developing countries is important for Uzbekistan to study investment attractiveness of the country, develop proposals and recommendations on increasing investment capital, foreign investments and loans [8].

DS Almatova. The monograph on regional peculiarities of investing in entrepreneurial activity presents scientific proposals and recommendations on justification and effective development of problems related to the development of investment and innovation activities of business entities in the regions [9].

Sh.Mustafakulov. The doctoral dissertation on "Improving the Scientific and Methodological Basis for Increasing the Investment Climate in Uzbekistan" will focus on the investment potential and economic potential of the region based on regional reserves, investment incentives, infrastructure status, foreign investment inflows and domestic investment. Scientific advice and recommendations on capacity building [11].

NG Karimov. The monograph on the issues of introducing market mechanisms for financing investment activity in the conditions of economic integration provides scientific and practical proposals on creation of new enterprises both inside and outside the country, modernization of existing enterprises, mastering of the latest technology and technology, increasing production level [13].

Sh.Mustafakulov. The potential of regions: A comparative analysis of theoretical and methodological approaches is presented in the scientific proposal to enhance the attractiveness of investments and the effectiveness of investment in regional development [11].

B.Yu.Khodiev, A.Bekmurodov, Sh.I.Mustafakulov, ME Pulatov. Based on the analytical data provided in the popular booklet of the State Program on Implementation of the Strategy of Action on the five priority directions of development of the Republic of Uzbekistan in the years 2017-2021, foreign direct investment and advanced foreign investments in the priority sectors of the national economy. scientific research on the use and development of bilateral and multilateral cooperation mechanisms to enhance the processes involved in the use of technology brief [10].

An article Which Ismatov R. O., Odiljanov Sh. Sh. The effective use of foreign investment in the modernization of industrial enterprises, The economy of the Republic of Uzbekistan, particularly in the manufacturing process of modernization in Namangan region, analysis of the state of the attraction of foreign investment in the launch of new enterprises and the proposals fo $r$ the effective use of foreign investments[11].

Ismatov R. O., Dadaboev T. Y., Karabaev Sh. A. (2019). Today, in many leading coutries, the provision of cheap and high-quality agricultural products to the population is one of the primary problems. The article examines the issues of effective provision of food safety in the country and its formation, including the issues of the sector, the essence of unvestment activity and its determinants[12].

\section{RESEARCH METHODOLOGY}

As the topic of our research is focused on improving the mechanisms of increasing investment attractiveness in maintaining macroeconomic balance, firstly, the research work of economists and researchers on the topic was studied. The methodology of the study was comparative analysis of the literature of economists and used the methods of statistical hypothesis testing to assess the importance of economic indicators.

\section{ANALYSIS AND RESULTS}

Currently, 456 projects worth 23 billion dollars are being implemented in our country through foreign investments.

Addressing the Parliament on the most important priorities for 2019, President of the Republic of Uzbekistan Sh.Mirziyoev highlighted the investment, saying, "World experience shows that the state pursued active investment policy has achieved sustainable growth of its economy.

That is why investing is a driver of the economy, in Uzbek words, the heart of the economy. 
In addition to investment, new technologies, best practices, highly qualified specialists come into various industries and sectors, and entrepreneurship develops dynamically.

Uzbekistan is currently a country ready for investment. Local policies, peacekeeping, and positive macroeconomic indicators are all important factors for active investment. It is not accidental that such a situation is of great interest to foreign investors as well.

At the present stage of radical change of the structure of the national economy, foreign direct investment is of great interest. The main ways to attract them are:

- establishment of joint ventures (including the sale of shares of Uzbek issuers to foreign investors);

- Registration of enterprises with foreign capital in Uzbekistan;

- Attraction of foreign capital on the basis of concessions;

- increase of free economic zones (FIEZ), aimed at active attraction of foreign investors to certain regions of the country.

Analysis of the structure of currently attracted foreign investments shows that most of these investments are for export-oriented sectors - fuel and energy complex, petrochemicals, gold mining and cotton processing industry, or high self-sufficiency, with shorter repayment periods profitable projects: trade, telecommunications, public catering, office and hotel buildings in major cities, food industry and financial services.

Particularly noteworthy is the work being done to attract investment to implement projects on structural transformation of the country's economy, modernization, technical and technological renovation of the sectors. In particular, if you look at sources of financing of investments into fixed capital in the Republic of Uzbekistan, in 2008 foreign investments and loans amounted to 2170.2 million US dollars, and in 2017 they reached 3348.2 million dollars, which is higher than in 2008. percent.

According to the data, total investment in fixed assets in the Republic of Uzbekistan for 20102017 increased almost 4.5 times. Its volume amounted to 15,338.7 billion soums in 2010 and increased to $68,423.9$ billion soums in 2017.

Investment in mining and quarrying at the beginning of the period amounted to UZS 1514.6 billion, and by the end of the period increased to 14,203.8 billion, or almost 9.4 times. This figure is more than twice the national average.

Dynamics of investment in fixed assets in industrial sectors of the economy of Uzbekistan also has a tendency to grow and in 2017 amounted to 1,2238.1 billion soums, with the volume of 2334.9 billion soums.

In 2017 , it increased by $524 \%$ compared to 2010 . In $2010,895.9$ billion soums were invested in electricity, gas, steam supply and air conditioning, while in 2017 their volume reached 5472.2 billion sums, or $611 \%$.

As a result of active investment policy in the country, over the past 20 years, the volume of reformed foreign direct investments and unsecured loans in the economy of the Republic of Uzbekistan amounted to US \$ 25.3 billion, of which US \$ 11.8 billion (47\%) has been attracted over the past 5 years. were made. In the last five years, foreign direct investment has attracted $73 \%$, oil and gas - $6 \%$, electricity - $2 \%$, light and textile - about $1 \%$ and automotive industry $-0.2 \%$. This shows that there is a strong need to diversify foreign investment in the economy.

By virtue of all sources, it is necessary to continue active investment policy, which is a key condition for the development of our economy, which is one of the top 10 tasks set in the year 2019 - the Year of Active Investment and Social Development. trillion soums, or 16\% more than in 2018

Table 1

Investment in fixed capital investments growth rates, in percent

\begin{tabular}{|c|c|c|c|c|c|c|c|c|c|c|c|}
\hline & $\mathbf{2 0 0}$ & $\mathbf{2 0 0}$ & $\mathbf{2 0 1}$ & $\mathbf{2 0 1}$ & $\mathbf{2 0 1}$ & $\mathbf{2 0 1}$ & $\mathbf{2 0 1}$ & $\mathbf{2 0 1}$ & $\mathbf{2 0 1}$ & $\mathbf{2 0 1}$ & $\begin{array}{c}\text { January } \\
\text { Indicators }\end{array}$ \\
& $\mathbf{8}$ & $\mathbf{9}$ & $\mathbf{0}$ & $\mathbf{1}$ & $\mathbf{2}$ & $\mathbf{3}$ & $\mathbf{4}$ & $\mathbf{5}$ & $\mathbf{6}$ & $\mathbf{7}$ & $\begin{array}{c}\text { Septemb } \\
\text { er 2018 }\end{array}$ \\
\hline \multirow{2}{*}{ Total investments } & 134 & 124 & 108 & 103 & 112 & 112 & 109 & 109 & 108 & 120 & 130,9 \\
\end{tabular}




\begin{tabular}{|l|c|c|c|c|c|c|c|c|c|c|c|}
\hline State budget & $\begin{array}{c}142 \\
, 7\end{array}$ & $\begin{array}{c}113 \\
, 5\end{array}$ & $\begin{array}{c}80, \\
6\end{array}$ & $\begin{array}{c}110 \\
, 6\end{array}$ & $\begin{array}{c}95 \\
3\end{array}$ & $\begin{array}{c}118 \\
, 1\end{array}$ & $\begin{array}{c}92, \\
9\end{array}$ & $\begin{array}{c}110 \\
, 1\end{array}$ & $\begin{array}{c}105 \\
, 7\end{array}$ & $\begin{array}{c}130 \\
, 6\end{array}$ & 87,5 \\
\hline Funds of enterprises & $\begin{array}{c}120 \\
, 7\end{array}$ & $\begin{array}{c}103 \\
, 2\end{array}$ & $\begin{array}{c}97, \\
9\end{array}$ & $\begin{array}{c}108 \\
, 1\end{array}$ & $\begin{array}{c}104 \\
, 7\end{array}$ & $\begin{array}{c}118 \\
, 8\end{array}$ & $\begin{array}{c}107 \\
, 6\end{array}$ & $\begin{array}{c}102 \\
, 7\end{array}$ & $\begin{array}{c}101 \\
, 6\end{array}$ & $\begin{array}{c}116 \\
, 7\end{array}$ & 133,6 \\
\hline Population & $\begin{array}{c}109 \\
, 0\end{array}$ & $\begin{array}{c}130 \\
, 5\end{array}$ & $\begin{array}{c}173 \\
, 9\end{array}$ & $\begin{array}{c}127 \\
, 6\end{array}$ & $\begin{array}{c}127 \\
, 7\end{array}$ & $\begin{array}{c}115 \\
, 6\end{array}$ & $\begin{array}{c}110 \\
, 8\end{array}$ & $\begin{array}{c}111 \\
, 8\end{array}$ & $\begin{array}{c}119 \\
, 8\end{array}$ & $\begin{array}{c}89, \\
6\end{array}$ & 104,4 \\
\hline Bank loans & $\begin{array}{c}141 \\
, 8\end{array}$ & $\begin{array}{c}129 \\
, 9\end{array}$ & $\begin{array}{c}200 \\
, 9\end{array}$ & $\begin{array}{c}122 \\
, 1\end{array}$ & $\begin{array}{c}106 \\
, 5\end{array}$ & $\begin{array}{c}104 \\
, 0\end{array}$ & $\begin{array}{c}119 \\
, 5\end{array}$ & $\begin{array}{c}115 \\
, 6\end{array}$ & $\begin{array}{c}100 \\
, 8\end{array}$ & $\begin{array}{c}137 \\
, 9\end{array}$ & 176,9 \\
\hline $\begin{array}{l}\text { Foreign investments } \\
\text { and loans }\end{array}$ & $\begin{array}{c}163 \\
, 6\end{array}$ & $\begin{array}{c}156 \\
, 9\end{array}$ & $\begin{array}{c}94 \\
1\end{array}$ & $\begin{array}{c}77, \\
8\end{array}$ & $\begin{array}{c}105 \\
, 8\end{array}$ & $\begin{array}{c}105 \\
, 6\end{array}$ & $\begin{array}{c}113 \\
, 0\end{array}$ & $\begin{array}{c}107 \\
, 9\end{array}$ & $\begin{array}{c}114 \\
, 5\end{array}$ & $\begin{array}{c}134 \\
, 9\end{array}$ & 132,9 \\
\hline $\begin{array}{l}\text { Fund for } \\
\text { Reconstruction and }\end{array}$ & $\begin{array}{c}147 \\
\text { Development }\end{array}$ & $\begin{array}{c}206 \\
, 7\end{array}$ & $\begin{array}{c}141 \\
, 3\end{array}$ & $\begin{array}{c}95, \\
1\end{array}$ & $\begin{array}{c}165 \\
, 0\end{array}$ & $\begin{array}{c}62, \\
6\end{array}$ & $\begin{array}{c}120 \\
, 8\end{array}$ & $\begin{array}{c}151 \\
, 9\end{array}$ & $\begin{array}{c}113 \\
, 6\end{array}$ & $\begin{array}{c}203 \\
, 2\end{array}$ & 131,9 \\
\hline $\begin{array}{l}\text { Children's Sports } \\
\text { Development Fund }\end{array}$ & $\mathrm{X}$ & $\mathrm{X}$ & $\mathrm{X}$ & $\mathrm{X}$ & $\mathrm{X}$ & $\mathrm{X}$ & $\mathrm{X}$ & $\begin{array}{c}97, \\
8\end{array}$ & $\begin{array}{c}102 \\
, 3\end{array}$ & $\begin{array}{c}42, \\
4\end{array}$ & 103,0 \\
\hline Off-budget funds & $\begin{array}{c}107 \\
, 0\end{array}$ & $\begin{array}{c}109 \\
, 9\end{array}$ & $\begin{array}{c}76 \\
2\end{array}$ & $\begin{array}{c}117 \\
, 0\end{array}$ & $\begin{array}{c}157 \\
, 3\end{array}$ & $\begin{array}{c}142 \\
, 6\end{array}$ & $\begin{array}{c}99 \\
0\end{array}$ & $\mathrm{X}$ & $\mathrm{X}$ & $\mathrm{X}$ & $\mathrm{X}$ \\
\hline State Targeted Bloods & $\mathrm{X}$ & $\mathrm{X}$ & $\mathrm{X}$ & $\mathrm{X}$ & $\mathrm{X}$ & $\mathrm{X}$ & $\mathrm{X}$ & $\begin{array}{c}107 \\
, 8\end{array}$ & $\begin{array}{c}87, \\
7\end{array}$ & $\begin{array}{c}84, \\
6\end{array}$ & 128,8 \\
\hline
\end{tabular}

Taking into account the fact that in $201916 \%$ of investments to the economy are planned to be mastered in 2018, and 1,5 times more foreign direct investment, they are directly related to the effectiveness of the reforms:

- creation of necessary conditions for radical improvement of the open economy, healthy competition, business and investment climate;

- Decrease in state participation in the economy, creation of new jobs through intensive development of the private sector;

- Ensuring high economic growth through modernization and diversification of the economy and increasing labor productivity;

- Fighting the shadow economy, drastically reducing its size;

- consistent policy of currency liberalization, implementation of stable monetary policy;

- training of qualified personnel capable of carrying out strategic tasks for economic development.

The third stage of implementing the Strategy of Action for the five priority areas of development of the Republic of Uzbekistan in 2017-2021. Implementation of a set of measures for the introduction of modern science, innovation ideas and technologies into the economy, social sector and public administration in 2018 We believe that the following should be taken seriously, as well as the consistent and effective continuation of an active investment policy:

1. Ensuring economic stability, including pricing, currency and credit stability. In:

- production of high-value, domestic demand and high quality products in the leading sectors of the economy, high-efficiency industries;

- support for the production of finished and competitive products based on the complete processing of limited and inexpensive local raw materials;

- development of measures to reduce the economy's response to price fluctuations in the external markets;

- consistent policy of currency liberalization, implementation of stable monetary policy;

- reducing the size of the "shadow" economy by further enhancing the openness of the economy by dramatically reducing government interference in managing the economy;

- development of free entrepreneurship and investment activity financing through the reduction of the shadow economy and, consequently, increased revenues of the State budget.

2. Further improvement of the system of efficient use of human capital.

In:

- increasing the efficiency of science, modern and continuous education;

- increasing the volume of investments in education, science and their targeted use; 
- Increasing the role of higher education institutions in the implementation of public reforms in the society and economy based on training highly educated, advanced and up-to-date knowledge and highly competitive, highly competitive professionals;

- promotion of healthy competition among higher education institutions of the state - foreign partnership and other forms;

- The realization of human, intellectual, labor, creative, managerial abilities and their effective use;

- to increase the scientific potential of higher education institutions, to expand the scope of training of scientific and scientific-pedagogical personnel, to improve their skills in foreign countries, to participate in international projects in research fields, and to continue the education of students with high knowledge and skills;

- effective use of their experience and recommendations on the basis of inviting qualified nationals and foreign specialists working in prestigious foreign educational, research and banking and financial institutions, manufacturing companies, international organizations;

- It is desirable to introduce a system of organization and implementation of scientific research in higher education and research institutions on the basis of orders from manufacturing companies.

3. Reducing unemployment among the population by increasing employment, increasing their real incomes and living standards. In this

- creation of new jobs;

- increasing family incomes;

- improvement of social security:

- radically changing the attitude of migrant workers to work abroad;

- Strengthening of a sense of patriotism, such as contributing to the prosperity of the country;

- increasing the availability of housing and other property through increasing the real incomes of the population;

- to increase their love for the profession through the blessing of their work;

- To be able to care for their children and to take care of their children on the basis of sufficient time and investment.

4. Strengthening the desire of the population and individuals to engage in entrepreneurial and investment activities through increasing the efficiency of the tax system and administration and reducing the tax burden. They include:

- increasing economic activity as an independent and potential subject, freely participating in economic reforms;

- It is desirable to increase social activity as a subject of public opinion and reaction, not indifferent to the reforms carried out by the state.

5. It is necessary to integrate innovative ideas and technologies into the economy, to achieve a dramatic increase in the share of the digital economy in GDP and in economic growth, and to rely on best international practices.

\section{CONCLUSION AND RECOMMENDATIONS}

In summary, economic growth cannot be achieved without improving investment activity. For this purpose; liberalization of the state mechanism of investment and expansion of market mechanisms. expanding the use of new methods such as project, co-financing and leasing.

\section{REFERENCES}

1. Mirziyoev Sh. Discussion on the implementation of prospective investment projects On July 26 , 2018, at the meeting of the Cabinet of Ministers chaired by President of the Republic of Uzbekistan Shavkat Mirziyo, the e-journal "Economy and Innovative Technologies" was launched. № 2, March-April, 2019 2/2019 (№ 00040) www.iqtisodiyot.uz 14 video-conference meeting was held. Information from the site http://uza.uz 2018 July 26th.

2. Mirziyoev Sh.M. Road Map on Improvement of Uzbekistan's Indicators in the Doing Business Report of the World Bank and International Finance Corporation by Decree of the President of the Republic of Uzbekistan № PP-3852 dated 13.07.2018. 
3. Mirziyoev Sh.M. State Program of Action of the President of the Republic of Uzbekistan on January 22, 2018 in the Year of Active Entrepreneurship, Innovative Ideas and Technologies Decree PF-5308.

4. Mirziyoev Sh.M. Shavkat-Mirziyoev-in-historical-speech watch 2017 September 20.

5. Mirziyoev Sh.M. Appeal to the Parliament. www.daryo.uz. 2017 December 22nd.

6. Begalov BA, Goyibnazarov BA, Kutliev OA, Gulyamov SS, Siddikov AJ, Jumaev KH, Hujakulov H., Khamraev Z., Ernazarov GB , Umarov FA .. Systematic analysis of structural and structural changes in the national economy. Monograph. State Committee of the Republic of Uzbekistan on Statistics. - T .: Statistical Materials Distribution Technical Support Department, $2018-269$ p.

7. Goyibnazarov BK Priority of training competitive personnel in the implementation of reforms in statistical activities. knowledge.stat.uz. 2018 year.

8. Siddikov A.J. The role of investment in the development of Uzbekistan and its attractiveness. knowledge.stat.uz. 2018 year.

9. Almatova D.S. Abstract of doctoral dissertation on theme: "Improvement of investments attraction for development of entrepreneurial activity in the regions" Tashkent. 2018

10. Khodiev B.Yu., Bekmurodov AS, Mustafakulov Sh.I., Pulatov ME A popular brochure on the study of the State Program on implementation of the Strategy of Action on the five priority directions of development of the Republic of Uzbekistan in the "Year of Dialogue with the People and Human Interests" in 2017-2021. - T: Enlightenment, 2017. - 268 p.

11. Mustafakulov Sh. Abstract of doctoral dissertation on theme: "Improving the scientific and methodological basis for increasing the attractiveness of the investment climate in Uzbekistan" Tashkent. 2017

12. Ismatov R. O., Odiljanov Sh. Sh. The effective use of foreign investment in the modernization of industrial enterprises ISSN 2409-1677 высшая школа раскрытие научной новизны исследований апрель (7) 2017.

13. Ismatov R. O., Dadaboev T. Y., Karabaev Sh. A. (2019). Investment possibilities in agricultural networks. ISJ Theoretical and Applied Science, 02 (70), 350-355.

14. Almatova D.S. Regional features of investment in business activities Monograph. $-\mathrm{T}$.: Publisher, 2013. 194 p.

15. Karimov N.G. Introduction of market mechanisms of financing investment activity in the conditions of economic integration: monograph. - T .: 2007, "Science and Technology," p.

16. Decree of the President of the Republic of Uzbekistan dated July 27, 2018 N UP-5490 "About measures for further improvement of the system of protection of the rights and legitimate interests of business entities". Scientific e-journal "Economics and Innovative Technologies". No. 2, March-April, 2019 2/2019 (No. 00040) www.iqtisodiyot.uz

17. The Decree of the President of the Republic of Uzbekistan dated February 7, 2017 № UP-4947 on measures for further implementation of the Strategy of action on five priority directions of development of the Republic of Uzbekistan in 2017-2021.

18. Decree of the President of the Republic of Uzbekistan dated June 19, 2017 N UP-5087 "On measures to radically improve the system of state protection of legitimate interests of business and further development of entrepreneurial activity".

19. The Decree of the President of the Republic of Uzbekistan dated September 5, 2017 № PF-5177 "On Priority Measures for Liberalization of the Foreign Exchange Policy".

20. Statistical Yearbook Collection of the State Statistics Committee of the Republic of Uzbekistan for 2010-2017.

21. Division of Investment and Enterprise United Nations Conference on Trade and Development, www.unctad.org, 2018.

22. Retrieved from the website https://uznet.press, parliament.gov.uz. Deputies discussed the 2019 Budget.

23. http://uza.uz 22. https://www.norma.uz 